University of Nebraska - Lincoln

DigitalCommons@University of Nebraska - Lincoln

Agronomy \& Horticulture -- Faculty Publications

Agronomy and Horticulture Department

2014

\title{
Multilocation Corn Stover Harvest Effects on Crop Yields and Nutrient Removal
}

\author{
Douglas L. Karlen \\ USDA-ARS, doug.karlen@ars.usda.gov \\ Stuart J. Birrell \\ lowa State University \\ Jane M.F. Johnson \\ USDA-ARS, Jane.johnson@ars.usda.gov \\ Shannon I. Osborne \\ USDA-ARS \\ Thomas E. Schumacher \\ South Dakota State University
}

See next page for additional authors

Follow this and additional works at: https://digitalcommons.unl.edu/agronomyfacpub

Part of the Agricultural Science Commons, Agriculture Commons, Agronomy and Crop Sciences Commons, Botany Commons, Horticulture Commons, Other Plant Sciences Commons, and the Plant Biology Commons

Karlen, Douglas L.; Birrell, Stuart J.; Johnson, Jane M.F.; Osborne, Shannon I.; Schumacher, Thomas E.; Varvel, Gary E.; Ferguson, Richard B.; Novak, Jeff M.; Frederick, James R.; Baker, John M.; Lamb, John A.; Alder, Paul R.; Roth, Greg W.; and Nafziger, Emerson D., "Multilocation Corn Stover Harvest Effects on Crop Yields and Nutrient Removal" (2014). Agronomy \& Horticulture -- Faculty Publications. 1023. https://digitalcommons.unl.edu/agronomyfacpub/1023

This Article is brought to you for free and open access by the Agronomy and Horticulture Department at DigitalCommons@University of Nebraska - Lincoln. It has been accepted for inclusion in Agronomy \& Horticulture -Faculty Publications by an authorized administrator of DigitalCommons@University of Nebraska - Lincoln. 


\section{Authors}

Douglas L. Karlen, Stuart J. Birrell, Jane M.F. Johnson, Shannon I. Osborne, Thomas E. Schumacher, Gary E. Varvel, Richard B. Ferguson, Jeff M. Novak, James R. Frederick, John M. Baker, John A. Lamb, Paul R. Alder, Greg W. Roth, and Emerson D. Nafziger 


\title{
Multilocation Corn Stover Harvest Effects on Crop Yields and Nutrient Removal
}

\author{
Douglas L. Karlen • Stuart J. Birrell • Jane M. F. Johnson • Shannon L. Osborne • \\ Thomas E. Schumacher • Gary E. Varvel • Richard B. Ferguson • Jeff M. Novak • \\ James R. Fredrick • John M. Baker • John A. Lamb • Paul R. Adler • Greg W. Roth • \\ Emerson D. Nafziger
}

Published online: 7 February 2014

(C) Springer Science+Business Media New York (outside the USA) 2014
This document is a U.S. government work and is not subject to copyright in the United States.

\begin{abstract}
Corn (Zea mays L.) stover was identified as an important feedstock for cellulosic bioenergy production because of the extensive area upon which the crop is already grown. This report summarizes 239 site-years of field research examining effects of zero, moderate, and high stover removal rates at 36 sites in seven different states. Grain and stover yields from all sites as well as N, P, and $\mathrm{K}$ removal from 28 sites are summarized for nine longitude and six latitude bands, two tillage practices (conventional vs no tillage), two stover-
\end{abstract}

\footnotetext{
D. L. Karlen $(\bowtie)$

USDA-Agricultural Research Service (ARS) National Laboratory for Agriculture and the Environment (NLAE), 2110 University

Boulevard, Ames, IA 50011, USA

e-mail: Doug.Karlen@ars.usda.gov

\section{S. J. Birrell}

Department of Agricultural and Biosystems Engineering, Iowa State University, 208 Davidson Hall, Ames, IA 50011, USA

J. M. F. Johnson

USDA-ARS-North Central Soil Conservation Research Laboratory

(NCSCRL), 803 Iowa Ave., Morris, MN 56267, USA
}

\section{S. L. Osborne}

USDA-ARS-North Central Agricultural Research Laboratory

(NCARL), 2923 Medary Ave., Brookings, SD 57006, USA

\section{T. E. Schumacher}

Plant Science Department, South Dakota State University, Plant

Science-Box 2140C, Brookings, SD 57006, USA

G. E. Varvel

USDA-ARS-Agroecosystem Management Research Unit (AMRU),

117 Keim Hall, Lincoln, NE 68583-0938, USA

\section{R. B. Ferguson}

Department of Agronomy, University of Nebraska-Lincoln, 367

Keim Hall, Lincoln, NE 68583, USA harvest methods (machine vs calculated), and two crop rotations \{continuous corn (maize) vs corn/soybean [Glycine max (L.) Merr.]\}. Mean grain yields ranged from 5.0 to $12.0 \mathrm{Mg} \mathrm{ha}^{-1}$ (80 to $192 \mathrm{bu} \mathrm{ac}^{-1}$ ). Harvesting an average of 3.9 or $7.2 \mathrm{Mg} \mathrm{ha}^{-1}$ (1.7 or 3.2 tons $\mathrm{ac}^{-1}$ ) of the corn stover resulted in a slight increase in grain yield at 57 and $51 \%$ of the sites, respectively. Average no-till grain yields were significantly lower than with conventional tillage when stover was not harvested, but not when it was collected. Plant samples

J. M. Novak

USDA-ARS-Costal Plains Soil, Water, \& Plant Research Center (CPSWPRC), 2611 West Lucas St., Florence, SC 29501, USA

J. R. Fredrick

Clemson University Pee Dee Research \& Education Center (PDREC), 2200 Pocket Road, Florence, SC 29501, USA

J. M. Baker

USDA-ARS, Soil and Water Management Research Unit, 439

Borlaug Hall 1991 Upper Buford Circle, St. Paul, MN 55108, USA

J. A. Lamb

Department of Soil, Water and Climate, University of Minnesota, S229 Soils Building, 1529 Gortner Avenue, St. Paul, MN 55108, USA

P. R. Adler

USDA-ARS-Pasture Systems \& Watershed Management Research Unit (PSWMRU), Building 3702 Curtin Road, University Park, PA 16802, USA

\section{G. W. Roth}

Department of Plant Science, Pennsylvania State University, 407 Agricultural Sciences and Industries Building, University Park, PA 16802, USA

\section{E. D. Nafziger}

Crop Science Department, University of Illinois, W-301 Turner Hall, 1102 S. Goodwin, Urbana, IL 61820, USA 
collected between physiological maturity and combine harvest showed that compared to not harvesting stover, N, P, and $\mathrm{K}$ removal was increased by $24,2.7$, and $31 \mathrm{~kg} \mathrm{ha}^{-1}$, respectively, with moderate $\left(3.9 \mathrm{Mg} \mathrm{ha}^{-1}\right)$ harvest and by $47,5.5$, and $62 \mathrm{~kg} \mathrm{ha}^{-1}$, respectively, with high $\left(7.2 \mathrm{Mg} \mathrm{ha}^{-1}\right)$ removal. This data will be useful for verifying simulation models and available corn stover feedstock projections, but is too variable for planning site-specific stover harvest.

Keywords Bioenergy · Sustainable feedstock production . Nutrient removal

\section{Introduction}

The 56.7 billion-liter ( 15 billion gallons) ceiling for corn grain ethanol imposed by the Renewable Fuel Standard (RFS2) within the Energy Independence and Security Act of 2007 [EISA or Public Law (P.L.) 110-140] is rapidly approaching. Therefore, information needs regarding potential impacts of harvesting biomass to produce 60.5 billion liters (16 billion gallons) of advanced biofuels are also increasing exponentially. Many of the challenges in predicting how RFS2 goals can be achieved, as well as critical research needs to do so, are discussed by Keeler et al. [1]. One of the most critical challenges is helping everyone associated with biomass production, collection, transport, storage, and use understand that corn stover, the aboveground material left in fields after grain harvest, is not a "waste" associated with grain production. Stover and other crop residues are essential drivers for many ecosystem services, including protection against soil erosion, provision of soil carbon, and cycling of essential plant nutrients that could easily be disrupted if an excessive amount of biomass is harvested for any use. To help strive for a balance between the economic drivers seeking to increase the amount of biomass that is harvested and the environmental service requirements that reduce actual stover availability, this report summarizes field research conducted by the USDA Agricultural Research Service (ARS) Resilient Economic Agricultural Practices (REAP) team and their university partners as part of the USDA-National Institute for Food and Agriculture (NIFA) Sun Grant Corn Stover Regional Partnership.

Corn stover was identified as a major feedstock for bioenergy production [2] primarily because of the vast area upon which the crop is grown. For example, from 2011 through 2013, corn was planted on an average of 39.4 million hectares $(97,272,000 \mathrm{ac})$ throughout the USA [3] and produced an average of 419 billion liters (11.9 billion bushels) of grain. To estimate potential stover availability based on grain yield, harvest index $(\mathrm{HI})$ values which indicate the quantity of harvestable biomass per unit total biomass produced [i.e., stover / (stover + grain)] can be used. Assuming an HI of 0.5 , the total quantity of corn stover associated with 11.9 billion bushels of grain would be 255 million megagrams (282 million tons). Based on numbers such as these, the US Environmental Protection Agency (EPA) concluded that corn stover was indeed "the most economical agricultural feedstock ... to meet the 16 billion gallon cellulosic biofuel requirement" [4]. They estimated that 7.8 billion gallons (29.5 billion liters) of ethanol would come from 82 million tons ( 74 million megagrams) of corn stover by 2022 , which is consistent with the projections by the U.S. Department of Energy (DOE) [5]. Similarly, after evaluating ethanol production from corn grain and stover with respect to energy use, energy security, and resource conservation metrics, Lavigne and Powers [6] concluded that using corn stover as a feedstock for advanced biofuels was more consistent with US national energy policy priorities than producing more biofuel from grain.

In addition to the quantity of stover produced each year, there are several other reasons for using corn stover as a biofuel feedstock. First, the practice will allow coproduction of food and fuel on the same land, thereby reducing concerns that biofuel production will result in significant and undesirable land use change [7]. Another important reason is the welldeveloped nature of corn production and the industry that supports it throughout the USA. Much of the infrastructure for producing, harvesting, and transporting corn residues already exists, and in terms of genetics, the corn industry has excelled at discovering fundamental knowledge about the species and translating that information into superior crop performance. As a result, the capacity to develop hybrids for coproduction of biomass and grain, as well as the research infrastructure for its expansion, already exists. Furthermore, the US Corn Belt has an extensive transportation infrastructure for moving agricultural materials from the field to storage and processing facilities and products to export markets outside the region. Time will tell, but collectively, these reasons suggest that emerging cellulosic biofuel and bioproduct industries will likely be developed using corn stover in the Midwest and migrate to other regions of the country where different feedstock materials will be more important [8].

For the Midwestern United States, several others [2, 9, 10] have also envisioned harvesting stover as a "win-win" management practice perceiving that stover is an underutilized resource that could be used as a feedstock and simultaneously reduce residue management costs that currently range from $\$ 45$ to $\$ 65 \mathrm{ha}^{-1}$ ( $\$ 20$ to $\$ 30 \mathrm{ac}^{-1}$ ) [11]. However, the decision to harvest corn stover for bioenergy or bioproduct development is not that simple, because stover also supports many ecosystem services [12-14] and its harvest will increase annual nutrient removal [15-17]. Several reviews [e.g., 18] and workshops (e.g., www.swcs.org/roadmap) have stressed the importance of corn stover for protection against wind and water erosion, improving soil aggregation and structure, increasing infiltration and water retention, and mitigating 
soil temperature fluctuations. Several of these issues are addressed in subsequent papers within this special issue of BioEnergy Research. The hypothesis for this research endeavor was that careful, science-based decisions must be used to identify locations and quantities of stover that can be harvested in a sustainable manner. This will require a combination of simulation modeling and broadscale projections to support the emerging biofuel and bioproduct industries.

To facilitate development of guidelines for sustainable corn stover feedstock production, our objective is to summarize 239 site-years of field research examining effects of zero, moderate, and high stover removal rates at 36 sites in seven different states (Fig. 1). Grain and stover yields from all sites as well as N, P, and K removal from 28 sites are summarized for nine longitude and six latitude bands, two tillage practices (conventional vs no-tillage), two stover-harvest methods (machine vs calculated), and two crop rotations.

\section{Materials and Methods}

The Sun Grant Regional Partnership (SGRP) was formed in 2008 by ARS REAP scientists, university extension and research faculty affiliated with the NIFA North Central Sun Grant Association, and engineers from the DOE Idaho National Laboratory (INL). The goals were to quantify the amount of corn stover produced at several locations and effects of moderate or high rates of stover harvest on subsequent grain yields and nutrient removal. A core experiment consisting of no-tillage (or the least amount of tillage necessary to establish a corn crop), three rates of stover harvest (none, moderate, and high), and four replications was agreed upon for each of the SGRP sites. In addition to the new experiments, several established long-term ARS and university field trials, designed to assess effects of crop residue harvest, were leveraged to build a more robust dataset for assessing the sustainability of these practices.

New and existing SGRP studies provided 239 site-years of data from 36 replicated field experiments (Table 1). Thirtyone study sites were within the traditional USA Corn/Soybean Belt (Fig. 1) because of the quantity of corn planted throughout that region. Four Pennsylvania sites were selected, even though the soils differ substantially from those in the Midwestern USA, because of increasing corn and soybean production in that area and ongoing complimentary research focused on quantifying greenhouse gas (GHG) loss from those production systems. Those 35 studies were conducted on loam, silt loam, clay loam, or silty clay loam soils. The 36th site, located on loamy sand in the Southeastern Coastal Plain near Florence, SC, was included because a similar multilocation stover harvest research was conducted at this location [19] following the 1970s energy crisis. Furthermore, it was hypothesized that if adverse effects of stover harvest were going to be detected quickly, it would more likely be on highly weathered loamy sand than on structured, heavy-textured soils in the Midwest. Primary tillage practices at the various sites included chisel plowing, moldboard plowing, disking, or strip tillage in addition to the core no-tillage treatment. The length of time for which stover was harvested at the various sites ranged from 5 to 12 years (Table 1 ), and overall, the sites represented nine longitudinal bands $\left(-96^{\circ},-95^{\circ},-94^{\circ},-93^{\circ}\right.$, $-91^{\circ},-89^{\circ},-88^{\circ},-79^{\circ}$, and $\left.-78^{\circ} \mathrm{W}\right)$ and six latitudes $\left(45^{\circ}\right.$, $44^{\circ}, 42^{\circ}, 41^{\circ}, 40^{\circ}$, and $34^{\circ} \mathrm{N}$ ) within the USA.

Grain yields were determined either by hand harvesting a known area within each treatment or by using various commercial combines to harvest the entire plot. Yields were adjusted to a constant water content of $155 \mathrm{~g} \mathrm{~kg}^{-1}$ for comparison among studies. Stover yields were also determined in several different ways including (1) collecting samples from a 2-m length of row and fractionating the biomass into (a) plant parts above the ear shank, (b) below the ear shank, (c) cobs, and (d) grain; (2) attaching a canvas tarp to a commercial-scale combine to collect all residue from each plot, weighing all of the residue, and then dividing and returning a portion to each plot to create removal rates of 0,50 , or $100 \%$ of the biomass; (3) harvesting with a single-pass combine designed to simultaneously collect grain and stover [15]; (4) collecting stover with a Hesston Stackhand ${ }^{1}$ after combining the grain; or (5) collecting stover with a commercial fail chopper after combining the grain. Stover mass was calculated using dry weights from the hand samples, or for the mechanically collected material, it was determined by weighing, subsampling, and drying a representative sample to a constant weight, so that the quantities of stover removed could be compared among sites at a water content of $0 \mathrm{~g} \mathrm{~kg}^{-1}$.

The range and overall mean values for grain and stover yield for all 36 studies as well as mean N, P, and $\mathrm{K}$ removal for the 28 studies where those parameters were measured were compiled and subjected to a meta-analysis using a SAS general linear model (GLM). Longitude, latitude, tillage, rotation, and stover harvest methods were evaluated for significant effects $(P \leq 0.1)$. For tillage assessments, no-tillage treatments were compared to all other primary tillage methods as a group (i.e., conventional tillage). Stover harvest methods were also compared using two groups: "machine harvest" for locations measuring stover removal mechanically versus "calculated" for locations using a harvest index, summation of plant fractions, or the difference between the measured amount of residue after removal compared to the amount calculated to be present from the hand samples.

\footnotetext{
${ }^{1}$ Mention of a trademark or proprietary product is for information only and does not represent an endorsement by the USDA Agricultural Research Service, Department of Energy, or any university partner associated with this project.
} 


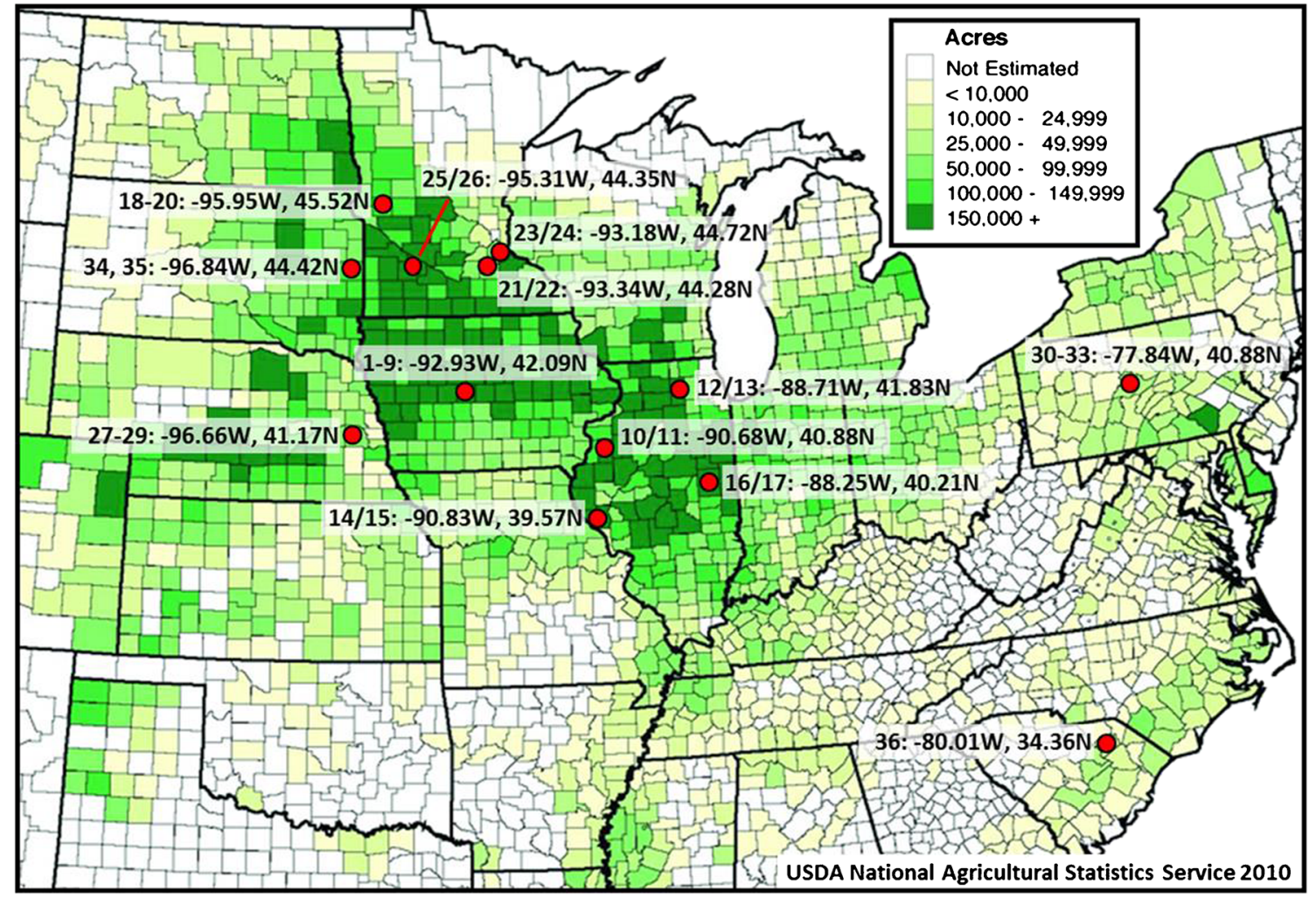

Fig. 1 Research sites from which corn grain and stover yields, nutrient composition, and other indicators of sustainable feedstock production were collected for the USDA-ARS Resilient Economic Agricultural Practices (REAP) and Sun Grant Regional Partnership project. The
National Agricultural Statistics Service (NASS) county-level acres of corn production in 2010 (the midpoint for this study) provide the background to illustrate relative production levels surrounding each site

\section{Results}

The 5-year range and mean grain yields for no, moderate, and high stover removal treatments at the 36 SGRP sites are presented in Table 2. County average National Agricultural Statistical Service (NASS) [3] grain yields were used as a reference to assess the relevancy of the various plot-scale yield measurements. Overall, grain yield from no stover removal treatments averaged $0.4 \mathrm{Mg} \mathrm{ha}^{-1}$ (6 bu ac${ }^{-1}$ ) less than the 5-year NASS average for the counties in which the studies were conducted. Moderate and high stover removal treatments averaged $0.1 \mathrm{Mg} \mathrm{ha}^{-1}$ (1.6 bu ac ${ }^{-1}$ ) less than the NASS average. Comparisons between the no-removal and moderate- or high-removal treatments show an increase of $0.3 \mathrm{Mg} \mathrm{ha}^{-1}$ (5 bu ac${ }^{-1}$ ), indicating that stover harvest resulted in a slight increase in average grain yield.

Table 3 presents the collection method, range, and 5-year average stover yield for moderate- and high-removal treatments. Values for sites 10 through 17 were calculated using a harvest index of 0.5 because there were no actual measurements of stover removal at any of the Illinois locations. The research protocol for high removal at those sites consisted of chopping stalks after grain harvest and then raking them off the entire plot. This technique left a considerable amount of fine material, but the weight was estimated to be less than $10 \%$ of the total biomass weight. Moderate removal (estimated at 50 to $60 \%$ ) at the Illinois sites was accomplished by raking the plots without chopping stalks. These practices were being used before these sites were incorporated into the SGRP and continued thereafter. When averaged for the 36 SGRP locations, the various methods used to quantify removal indicated that 3.9 or $7.2 \mathrm{Mg} \mathrm{ha}^{-1}$ (1.7 or 3.2 tons $\mathrm{ac}^{-1}$ ) of stover was harvested for the moderate- and high-removal treatments, respectively. Grain yield for both treatments (Table 2) averaged $10.1 \mathrm{Mg} \mathrm{ha}^{-1}$ (160 bu ac ${ }^{-1}$ ); therefore, the average stover removal in these studies accounted for 46 or $85 \%$ of the aboveground biomass, respectively. Furthermore, harvesting an average of 3.9 or 7.2 $\mathrm{Mg} \mathrm{ha}{ }^{-1}$ of corn stover resulted in a slight increase in grain yield at 57 and $51 \%$ of the sites, respectively.

Stover harvest increased mean annual N, P, and $\mathrm{K}$ removal by an average of $24,2.7$, and $31 \mathrm{~kg} \mathrm{ha}^{-1}$ (22, 2.4, and $28 \mathrm{lb} \mathrm{ac}^{-1}$ ), respectively, for the moderate-removal treatment and by $47,5.5$, and $62 \mathrm{~kg} \mathrm{ha}^{-1}\left(42,4.9\right.$, and $\left.55 \mathrm{lb} \mathrm{ac}{ }^{-1}\right)$, respectively, for the high-removal treatment. Nutrient removal measurements were not made for Illinois sites because those studies were designed and implemented before the SGRP was formed and criteria for the core experiment were established.

A meta-analysis using the mean data (Tables 2, 3, and 4) for each of the 36 experiments was conducted to evaluate 


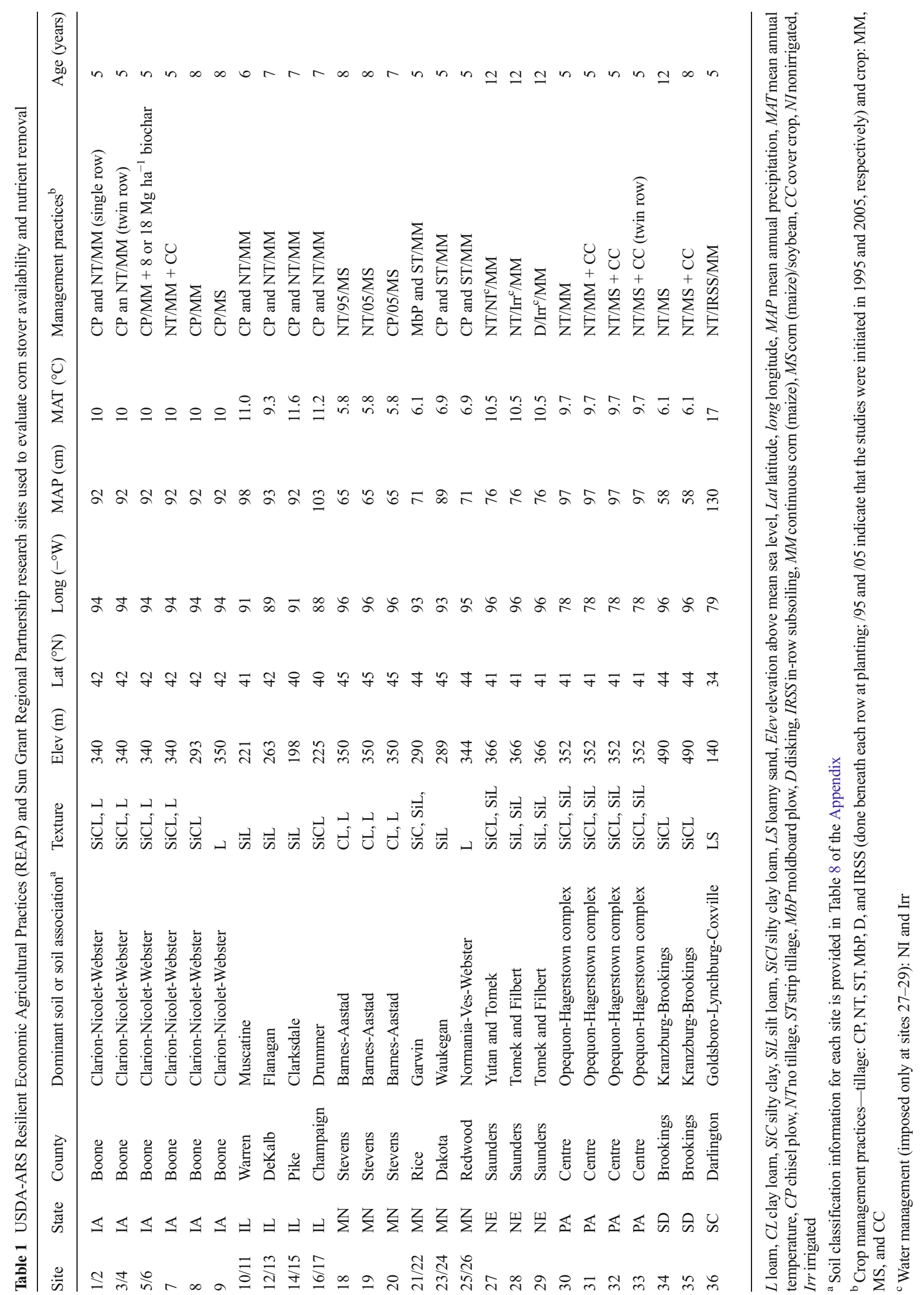


Table 2 Five-year (2008-2012) NASS survey and measured corn grain yields for three stover harvest strategies at 36 research sites associated with the USDA-ARS Resilient Economic Agricultural Practices (REAP) and Sun Grant Regional Partnership

\begin{tabular}{|c|c|c|c|c|c|c|c|c|}
\hline \multirow[t]{2}{*}{ Site } & \multicolumn{2}{|c|}{ NASS yields ${ }^{\mathrm{a}}$} & \multicolumn{2}{|c|}{ No removal } & \multicolumn{2}{|c|}{ Moderate removal } & \multicolumn{2}{|c|}{ High removal } \\
\hline & Range & Mean & Range & Mean & Range & Mean & Range & Mean \\
\hline & \multicolumn{8}{|c|}{$\mathrm{Mg} \mathrm{ha}^{-1}$ at $155 \mathrm{~g} \mathrm{~kg}^{-1}$ water content } \\
\hline 1 & $9.2-11.5$ & 10.6 & $6.5-11.8$ & 9.6 & $9.5-12.5$ & 11.0 & $8.6-13.1$ & 10.9 \\
\hline 2 & $9.2-11.5$ & 10.6 & $7.9-10.9$ & 9.8 & $8.5-12.0$ & 10.4 & $8.8-12.9$ & 11.0 \\
\hline 3 & $9.2-11.5$ & 10.6 & $7.2-12.4$ & 9.9 & $8.5-12.4$ & 10.9 & $8.9-12.3$ & 11.0 \\
\hline 4 & $9.2-11.5$ & 10.6 & $8.1-11.0$ & 10.0 & $8.9-12.3$ & 11.0 & $8.9-12.4$ & 10.7 \\
\hline 5 & $9.2-11.5$ & 10.6 & $7.3-11.2$ & 9.7 & $8.9-12.7$ & 11.1 & $8.5-13.1$ & 11.1 \\
\hline 6 & $9.2-11.5$ & 10.6 & $8.7-12.3$ & 10.4 & $8.8-12.5$ & 10.8 & $9.7-13.1$ & 11.4 \\
\hline 7 & $9.2-11.5$ & 10.6 & - & - & $8.7-11.9$ & 10.5 & $8.6-12.9$ & 11.0 \\
\hline 8 & $9.2-11.5$ & 10.6 & $7.8-11.4$ & 9.4 & $8.2-12.0$ & 9.7 & $7.8-12.0$ & 9.5 \\
\hline 9 & $9.2-11.5$ & 10.6 & $11.3-13.0$ & 12.3 & $11.3-12.8$ & 12.2 & $10.6-13.2$ & 12.0 \\
\hline 10 & $9.6-13.0$ & 11.2 & $11.6-16.5$ & 14.3 & $11.3-16.7$ & 14.0 & $11.7-16.4$ & 14.2 \\
\hline 11 & $9.6-13.0$ & 11.2 & $10.2-15.4$ & 12.9 & $10.4-15.9$ & 13.7 & $10.9-16.4$ & 14.1 \\
\hline 12 & $10.0-11.9$ & 11.0 & $6.7-13.5$ & 10.8 & $7.0-14.2$ & 11.2 & $6.8-14.4$ & 11.3 \\
\hline 13 & $10.0-11.9$ & 11.0 & $4.6-13.7$ & 9.4 & $5.7-14.5$ & 10.6 & $4.6-14.0$ & 10.5 \\
\hline 14 & $5.7-10.6$ & 8.8 & $14.8-14.1$ & 9.7 & $1.4-14.4$ & 9.6 & $2.2-13.0$ & 10.0 \\
\hline 15 & $5.7-10.6$ & 8.8 & $4.1-14.1$ & 9.2 & $2.7-12.8$ & 9.6 & $1.7-14.0$ & 9.9 \\
\hline 16 & $6.8-11.9$ & 10.1 & $7.4-13.2$ & 10.9 & $5.4-12.6$ & 10.0 & $6.2-12.9$ & 10.2 \\
\hline 17 & $6.8-11.9$ & 10.1 & $4.2-11.6$ & 8.8 & $5.2-12.2$ & 9.4 & $4.8-12.3$ & 9.5 \\
\hline 18 & $8.8-11.7$ & 10.3 & $7.2-12.5$ & 9.0 & $7.4-12.5$ & 9.2 & $5.7-12.7$ & 9.0 \\
\hline 19 & $8.8-11.7$ & 10.3 & $8.6-13.3$ & 10.4 & $9.0-11.9$ & 10.3 & $9.0-11.1$ & 10.0 \\
\hline 20 & $8.8-11.7$ & 10.3 & $9.0-13.2$ & 10.4 & $9.2-13.5$ & 10.7 & $8.6-14.2$ & 11.1 \\
\hline 21 & $10.0-12.0$ & 11.2 & $9.7-12.2$ & 10.8 & $9.8-11.0$ & 10.3 & $9.7-11.5$ & 10.4 \\
\hline 22 & $10.0-12.0$ & 11.2 & $10.4-11.6$ & 10.8 & $9.8-10.9$ & 10.4 & $9.7-11.0$ & 10.3 \\
\hline 23 & $9.4-11.9$ & 11.0 & $6.5-10.4$ & 9.1 & $6.3-8.9$ & 7.5 & $7.9-10.8$ & 9.7 \\
\hline 24 & $9.4-11.9$ & 11.0 & $6.4-10.5$ & 8.1 & $6.8-9.7$ & 8.3 & $7.0-8.6$ & 7.7 \\
\hline 25 & $9.5-11.7$ & 10.8 & $8.6-10.6$ & 9.5 & $8.5-9.3$ & 8.9 & $8.4-9.7$ & 9.0 \\
\hline 26 & $9.5-11.7$ & 10.8 & $7.7-9.9$ & 8.6 & $8.4-9.1$ & 8.8 & $8.6-9.2$ & 8.9 \\
\hline 27 & $7.4-10.3$ & 9.0 & $3.4-10.4$ & 6.5 & - & - & $2.1-9.2$ & 6.4 \\
\hline 28 & $11.2-13.4$ & 12.0 & $9.1-14.2$ & 11.6 & $9.1-14.7$ & 12.4 & $8.6-14.6$ & 12.6 \\
\hline 29 & $11.2-13.4$ & 12.0 & $8.0-13.0$ & 13.2 & $8.4-15.2$ & 12.9 & $8.3-14.6$ & 12.9 \\
\hline 30 & $5.8-8.5$ & 7.8 & $3.9-10.6$ & 8.3 & $5.0-10.7$ & 8.7 & $4.1-10.8$ & 8.4 \\
\hline 31 & $5.8-8.5$ & 7.8 & $5.1-10.1$ & 8.5 & $5.0-10.5$ & 8.5 & $4.4-10.7$ & 8.2 \\
\hline 32 & $5.8-8.5$ & 7.8 & $5.3-10.9$ & 8.6 & $5.3-10.7$ & 8.4 & $4.2-10.5$ & 8.0 \\
\hline 33 & $5.8-8.5$ & 7.8 & $3.6-10.7$ & 8.0 & $4.6-10.9$ & 8.7 & $2.3-11.0$ & 7.5 \\
\hline 34 & $8.2-10.1$ & 9.4 & $4.6-9.8$ & 7.0 & $5.2-10.4$ & 7.2 & $2.8-13.5$ & $7.3^{\mathrm{b}}$ \\
\hline 35 & $8.2-10.1$ & 9.4 & $4.0-9.8$ & 6.9 & $5.3-10.5$ & 7.2 & $2.6-13.0$ & $7.1^{\mathrm{b}}$ \\
\hline 36 & $2.9-7.6$ & 5.3 & $1.3-11.4$ & 5.8 & $0.6-9.1$ & 5.0 & $0.8-10.0$ & 5.8 \\
\hline \multicolumn{2}{|c|}{ Overall means } & 10.2 & & 9.8 & & 10.1 & & 10.1 \\
\hline
\end{tabular}

${ }^{a}$ These are 5-year NASS averages (2008-2012) for all corn grain production practices

${ }^{\mathrm{b}}$ Grain yields estimated following whole plant harvest of aboveground biomass and using a harvest index of 0.5

longitude, latitude, tillage, crop rotation, and stover harvest method effects across all locations (Tables 5, 6, and 7). As expected, maximum average grain yields for all three stover harvest treatments were found between $-88^{\circ}$ and $-94^{\circ} \mathrm{W}$ longitude and $41^{\circ}$ and $42^{\circ} \mathrm{N}$ latitude, reflecting the high yield potential within the center portion of the US Corn Belt. Statistically, however, the longitude and latitude bands were significantly different only when comparing the Florence, SC 
Table 3 Five-year (2008-2012) corn stover production averages from 36 research sites associated with the USDA-ARS Resilient Economic Agricultural Practices (REAP) and Sun Grant Regional Partnership
${ }^{a}$ Stover amounts were calculated based on grain yield assuming a harvest index of 0.5 and removal rates of $50 \%$ for partial removal and $90 \%$ for high removal

${ }^{\mathrm{b}}$ Removal rates were estimated by subtracting the amount of surface residue measured after harvest from the calculated aboveground biomass based on a 2-m row length collected by hand

${ }^{\mathrm{c}}$ Stover amounts were calculated using data from a 2-m row length collected by hand. Partial removal included cobs plus all material above the ear node. High removal estimates included cobs and all vegetative material above $10 \mathrm{~cm}$ from the soil surface

${ }^{\mathrm{c}}$ Maximum stover harvest was calculated by subtracting grain yield from moderate harvest from weights obtained when the entire plant was harvested using a commercial silage chopper

d A canvas "diaper" was attached to the combine to collect all stover material. At the end of each plot, the material was weighed. For partial removal plots, $50 \%$ was returned and spread uniformly across each plot. All collected material was removed for the "high removal" treatment

\begin{tabular}{|c|c|c|c|c|c|}
\hline \multirow[t]{2}{*}{ Site } & \multirow[t]{2}{*}{ Stover collection or estimation method } & \multicolumn{2}{|c|}{ Moderate removal } & \multicolumn{2}{|c|}{ High removal } \\
\hline & & Range & Mean & Range & Mean \\
\hline & & \multicolumn{4}{|c|}{$\mathrm{Mg} \mathrm{ha}^{-1}$ at $0 \mathrm{~g} \mathrm{~kg}^{-1}$ water content } \\
\hline 1 & Single pass, combine & $2.8-5.3$ & 3.9 & $4.1-7.1$ & 5.8 \\
\hline 2 & Single pass, combine & $1.9-5.6$ & 3.9 & $4.7-8.0$ & 6.1 \\
\hline 3 & Single pass, combine & $3.2-6.2$ & 4.4 & $5.3-7.3$ & 6.2 \\
\hline 4 & Single pass, combine & $3.2-6.3$ & 4.7 & $5.4-7.2$ & 6.0 \\
\hline 5 & Single pass, combine & $3.0-5.6$ & 4.2 & $4.3-6.6$ & 5.8 \\
\hline 6 & Single pass, combine & $3.3-5.7$ & 4.3 & $4.3-7.2$ & 6.1 \\
\hline 7 & Single pass, combine & $2.5-5.9$ & 3.8 & $5.0-6.7$ & 6.0 \\
\hline 8 & Single pass, combine & $2.1-5.0$ & 3.6 & $2.8-6.4$ & 4.9 \\
\hline 9 & Single pass, combine & $2.4-5.1$ & 4.3 & $3.0-7.1$ & 5.7 \\
\hline 10 & Calculated $^{\mathrm{a}}$ & $4.8-7.0$ & 5.9 & $8.9-12.5$ & 10.8 \\
\hline 11 & Calculated $^{\mathrm{a}}$ & $4.4-6.7$ & 5.8 & $8.3-12.5$ & 10.7 \\
\hline 12 & Calculated $^{\mathrm{a}}$ & $3.0-6.0$ & 4.7 & $5.2-11.0$ & 8.6 \\
\hline 13 & Calculated $^{\mathrm{a}}$ & $2.4-6.1$ & 4.5 & $3.5-10.6$ & 8.0 \\
\hline 14 & Calculated $^{\mathrm{a}}$ & $0.6-6.0$ & 4.1 & $1.7-9.9$ & 7.6 \\
\hline 15 & Calculated $^{\mathrm{a}}$ & $1.1-5.4$ & 4.0 & $1.3-10.6$ & 7.6 \\
\hline 16 & Calculated $^{\mathrm{a}}$ & $2.3-5.3$ & 4.2 & $4.7-9.8$ & 7.8 \\
\hline 17 & Calculated $^{\mathrm{a}}$ & $2.2-5.1$ & 4.0 & $3.6-9.4$ & 7.2 \\
\hline 18 & Calculated $^{\mathrm{b}}$ & $0.9-6.6$ & 3.5 & $3.0-9.4$ & 6.0 \\
\hline 19 & Calculated $^{\mathrm{b}}$ & $1.5-7.0$ & 4.2 & $3.7-12.4$ & 7.0 \\
\hline 20 & Calculated $^{\mathrm{b}}$ & $1.5-7.0$ & 4.0 & $3.6-10.4$ & 6.8 \\
\hline 21 & Calculated $^{\mathrm{c}}$ & $3.3-4.2$ & 3.8 & $7.7-8.0$ & 7.9 \\
\hline 22 & Calculated $^{\mathrm{c}}$ & $3.1-4.2$ & 3.7 & $7.8-7.9$ & 7.9 \\
\hline 23 & Calculated $^{\mathrm{c}}$ & $2.0-3.8$ & 2.9 & $5.8-8.6$ & 7.6 \\
\hline 24 & Calculated $^{\mathrm{c}}$ & $1.9-3.1$ & 2.5 & $4.7-7.2$ & 6.1 \\
\hline 25 & Calculated $^{\mathrm{c}}$ & $2.9-4.4$ & 3.6 & $6.1-9.1$ & 7.6 \\
\hline 26 & Calculated $^{\mathrm{c}}$ & $3.1-4.5$ & 3.6 & $5.9-9.7$ & 7.3 \\
\hline 27 & 2nd pass, flail chopper & - & - & $1.6-5.0$ & 3.2 \\
\hline 28 & 2nd pass, flail chopper & $1.7-5.4$ & 3.2 & $3.4-8.7$ & 6.4 \\
\hline 29 & 2nd pass, flail chopper & $1.9-4.7$ & 3.4 & $3.6-9.0$ & 6.6 \\
\hline 30 & 2nd pass, Stackhand & $1.7-3.4$ & 2.7 & $4.0-9.2$ & 6.9 \\
\hline 31 & 2nd pass, Stackhand & $1.8-3.4$ & 2.8 & $3.9-7.8$ & 6.1 \\
\hline 32 & 2nd pass, Stackhand & $1.5-3.5$ & 2.7 & $3.9-9.1$ & 6.5 \\
\hline 33 & 2nd pass, Stackhand & $1.8-4.2$ & 3.3 & $4.4-9.2$ & 6.8 \\
\hline 34 & 2nd-pass, flail chopper & $0.8-6.8$ & 2.8 & $5.4-27.3$ & $12.4^{\mathrm{c}}$ \\
\hline 35 & 2nd pass, flail chopper & $1.0-6.9$ & 2.8 & $5.2-26.5$ & $11.9^{\mathrm{c}}$ \\
\hline 36 & Single pass, diaper ${ }^{\mathrm{d}}$ & $2.5-8.4$ & 6.1 & $3.9-9.0$ & 6.4 \\
\hline
\end{tabular}

site $\left(-79^{\circ} \mathrm{W}\right.$ longitude, $34^{\circ} \mathrm{N}$ latitude) with the Midwestern sites, presumably because of the high amount of variation due to seasonal weather patterns and other factors.

Comparisons between sites with continuous corn versus a corn/soybean rotation showed no significant differences (Table 6) even though mean rotated yields were lower for all three stover harvest treatments. Since corn grain yields are generally 5 to $20 \%$ higher when grown in rotation [20], this unexpected response probably occurred because for the meta-analysis, most rotation sites were located in the northern and western portions of the study area (Table 1). Table 6 also shows that mean stover yield for both moderate- and highremoval treatments was higher for sites where removal quantities were calculated than where stover was actually collected, weighed, and adjusted to a water content of $0 \mathrm{~g} \mathrm{~kg}^{-1}$. Furthermore, differences in harvest methods were also reflected in mean grain yields for all three stover removal treatments. 
Table 4 Five-year average N, P, and $\mathrm{K}$ removal due to stover harvest from 28 research sites associated with the USDA-ARS Resilient Economic Agricultural Practices (REAP) and Sun Grant Regional Partnership

\begin{tabular}{|c|c|c|c|c|c|c|}
\hline \multirow[t]{2}{*}{ Site } & \multicolumn{3}{|c|}{ Moderate removal } & \multicolumn{3}{|c|}{ High removal } \\
\hline & $\mathrm{N}$ & $P$ & $\mathrm{~K}$ & $\mathrm{~N}$ & $\mathrm{P}$ & $\mathrm{K}$ \\
\hline & \multicolumn{6}{|c|}{$\mathrm{kg} \mathrm{ha}^{-1}$} \\
\hline 1 & 22 & 2.7 & 31 & 35 & 4.4 & 52 \\
\hline 2 & 22 & 2.5 & 33 & 37 & 4.1 & 52 \\
\hline 3 & 26 & 3.0 & 35 & 38 & 4.2 & 52 \\
\hline 4 & 28 & 3.3 & 37 & 35 & 3.8 & 46 \\
\hline 5 & 23 & 2.7 & 34 & 32 & 3.7 & 48 \\
\hline 6 & 23 & 2.8 & 38 & 34 & 4.0 & 53 \\
\hline 7 & 21 & 2.7 & 33 & 34 & 4.1 & 54 \\
\hline 8 & 21 & 2.0 & 24 & 30 & 2.7 & 33 \\
\hline 9 & 28 & 2.8 & 26 & 34 & 2.7 & 31 \\
\hline $18^{\mathrm{a}}$ & 35 & 2.6 & 23 & 61 & 5.0 & 37 \\
\hline 19 & 32 & 2.0 & 26 & 59 & 4.3 & 44 \\
\hline 20 & 32 & 2.1 & 26 & 57 & 4.4 & 46 \\
\hline 21 & 23 & 2.6 & 34 & 48 & 5.5 & 94 \\
\hline 22 & 25 & 3.8 & 32 & 50 & 4.8 & 84 \\
\hline 23 & 17 & 2.5 & 19 & 52 & 6.0 & 67 \\
\hline 24 & 14 & 1.5 & 18 & 30 & 5.7 & 36 \\
\hline 25 & 21 & 1.5 & 28 & 45 & 2.4 & 48 \\
\hline 26 & 21 & 1.5 & 27 & 43 & 2.6 & 45 \\
\hline $27^{\mathrm{b}}$ & - & - & - & 29 & 3.9 & 60 \\
\hline 28 & 32 & 4.2 & 58 & 56 & 7.3 & 98 \\
\hline 29 & 32 & 4.2 & 50 & 62 & 9.0 & 97 \\
\hline 30 & 20 & 2.2 & 32 & 50 & 5.1 & 71 \\
\hline 31 & 21 & 2.1 & 31 & 43 & 4.8 & 75 \\
\hline 32 & 20 & 2.3 & 30 & 49 & 5.4 & 70 \\
\hline 33 & 26 & 2.7 & 38 & 48 & 5.3 & 76 \\
\hline 34 & 20 & 3.8 & 22 & 86 & 17.2 & 100 \\
\hline 35 & 25 & 3.7 & 22 & 97 & 16.0 & 97 \\
\hline 36 & 26 & 3.7 & 37 & 54 & 5.7 & 73 \\
\hline Mean & 24 & 2.7 & 31 & 47 & 5.5 & 62 \\
\hline
\end{tabular}

${ }^{a}$ Samples from the Illinois sites (nos. 10-17) were not analyzed for nutrient composition because those sites were incorporated into the regional project 3 years after the SGRP was initiated and nutrient analysis was not part of the established protocol

${ }^{\mathrm{b}}$ There was no "moderate" removal for the nonirrigated Lincoln, NE site, and therefore, there were no estimates of nutrient removal

Comparisons between conventional- and no-tillage practices showed a significant difference $(P \leq 0.1)$ for no-removal grain yields $\left[10.7\right.$ vs $8.9 \mathrm{Mg} \mathrm{ha}^{-1}$ (170 vs $142 \mathrm{bu} \mathrm{ac}^{-1}$ ), respectively], but not for either the moderate- or highremoval treatments even though the yield trends were the same (i.e., 10.7 vs 9.4 and 10.9 vs $9.2 \mathrm{Mg} \mathrm{ha}^{-1}$, respectively). For stover yield and nutrient removal, there were no significant differences due to tillage (Table 7). Comparisons between the two stover harvest methods also showed no significant differences in N, P, or K removal (Table 7).

\section{Discussion}

Muth et al. [21] concluded that for sustainable corn stover harvest, substantially more subfield-scale research is needed to understand subtle differences among locations, soil resources, weather patterns, and management practices such as tillage, hybrid selection, or use of cover crops. We agree and caution readers not to use these multilocation means for sitespecific planning or developing stover harvest strategies. Rather, this extensive, 239 site-year dataset should be viewed as one of the most comprehensive research efforts to provide replicated field validation for projections such as those in the revised Billion Ton Report [5].

Agreement between the zero removal yields and county average NASS data [3] confirms that the research sites were representative of their respective areas. Similarly, the slight increase in average grain yield when stover was removed suggests that producers may want to consider moderate stover harvest to help overcome stover management problems and costs [11] rather than using more aggressive tillage practices to incorporate the nongrain material $[13,15,16]$. However, the quantity of stover to harvest is a very site- and perhaps seasonally specific decision [21]. This is especially true for more northern and western portions of the US Corn/Soybean Belt $[12,14]$.

Additional considerations influencing the sustainable amount of stover harvest and emphasizing the importance of subfield decision making [21] are presented in other papers within this special issue of BioEnergy Research dedicated to summarizing the comprehensive, multilocation SGRP project. Furthermore, because of the need for site-specific information to guide local decision making regarding the quantity and frequency of stover harvest, readers are encouraged to watch for additional, detailed publications for each of the 36 studies that contributed to this SGRP assessment.

The quantity of stover harvested at all SGRP sites showed substantial seasonal variability (Table 3 ) due to differences in growing conditions (i.e., planting dates, rainfall, temperature patterns, etc.), field-specific lodging caused by severe wind storms, and/or yield loss due to drought or hail. This variability confirms that stover harvest decisions must be site specific and even subfield specific to ensure they are sustainable [21].

The meta-analysis showed no significant differences in $\mathrm{N}$, $\mathrm{P}$, and $\mathrm{K}$ removal due to tillage (Table 7) but did show differences between sampling methods for $\mathrm{P}$ and $\mathrm{K}$ removal within the moderate stover harvest treatment. Nutrient concentrations (data not presented) within the various stover sample fraction were quite similar, so as expected, removal 
Table 5 Mean corn grain and stover yields for longitude and latitude locations associated with a meta-analysis of data representing 239 site-years of replicated field studies from 36 research sites associated with the USDA-ARS Resilient Economic Agricultural Practices (REAP) and Sun Grant Regional Partnership
${ }^{\mathrm{a}}$ Grain yields at a water content of $155 \mathrm{~g} \mathrm{~kg}^{-1}$

${ }^{\mathrm{b}}$ Stover yield at a water content of $0 \mathrm{~g} \mathrm{~kg}^{-1}$

\begin{tabular}{|c|c|c|c|c|c|}
\hline Factor & $\begin{array}{l}\text { Grain }^{\mathrm{a}} \\
\text { (no removal, } \\
\mathrm{Mg} \mathrm{ha}^{-1} \text { ) }\end{array}$ & $\begin{array}{l}\text { Grain } \\
\text { (moderate } \\
\text { removal, } \mathrm{Mg} \mathrm{ha}^{-1} \text { ) }\end{array}$ & $\begin{array}{l}\text { Grain } \\
\text { (high removal, } \\
\mathrm{Mg} \mathrm{ha}^{-1} \text { ) }\end{array}$ & $\begin{array}{l}\text { Stover }^{\mathrm{b}} \\
\text { (moderate } \\
\text { removal, } \mathrm{Mg} \mathrm{ha}^{-1} \text { ) }\end{array}$ & $\begin{array}{l}\text { Stover } \\
\text { (high removal, } \\
\mathrm{Mg} \mathrm{ha}^{-1} \text { ) }\end{array}$ \\
\hline \multicolumn{6}{|c|}{ Longitude $\left(-^{\circ} \mathrm{W}\right)$} \\
\hline 96 & 9.38 & 9.98 & 9.55 & 3.41 & 7.54 \\
\hline 95 & 9.05 & 8.85 & 8.95 & 3.60 & 7.45 \\
\hline 94 & 10.14 & 10.84 & 10.96 & 4.12 & 5.84 \\
\hline 93 & 9.70 & 9.12 & 9.52 & 3.22 & 7.38 \\
\hline 91 & 11.52 & 11.72 & 12.05 & 4.95 & 9.18 \\
\hline 89 & 10.10 & 10.90 & 10.90 & 4.60 & 8.30 \\
\hline 88 & 9.85 & 9.70 & 9.85 & 4.10 & 7.50 \\
\hline 79 & 5.80 & 5.00 & 5.80 & 6.10 & 6.40 \\
\hline 78 & 8.35 & 8.58 & 8.02 & 2.88 & 6.58 \\
\hline $\operatorname{LSD}_{(0.10)}$ & 2.37 & 1.45 & 2.33 & 0.77 & 1.44 \\
\hline \multicolumn{6}{|c|}{ Latitude $\left({ }^{\circ} \mathrm{N}\right)$} \\
\hline 45 & 9.40 & 9.20 & 9.50 & 3.42 & 6.70 \\
\hline 44 & 8.93 & 8.80 & 8.83 & 3.38 & 9.17 \\
\hline 42 & 10.13 & 10.85 & 10.94 & 4.21 & 6.29 \\
\hline 41 & 10.21 & 10.91 & 10.26 & 3.72 & 7.11 \\
\hline 40 & 9.65 & 9.65 & 9.90 & 4.08 & 7.55 \\
\hline 34 & 5.80 & 5.00 & 5.8 & 6.10 & 6.40 \\
\hline $\operatorname{LSD}_{(0.10)}$ & 2.10 & 1.29 & 2.06 & 0.68 & 1.28 \\
\hline
\end{tabular}

was proportional to stover yield. Among the locations (Table 4), there was substantially more variation in nutrient removal than might be implied by the overall means. This presumably reflected differences among hybrids grown at the various locations, since nutrient uptake and removal patterns are controlled by corn genetics, environmental conditions, and their interactions. Another factor contributing to the site-specific variation was the time of sample collection. Nutrient concentrations in stover samples collected closer to physiologic maturity were

Table 6 Mean corn grain and stover yields for rotation and stover harvest method associated with a meta-analysis of data representing 239 siteyears of replicated field studies from 36 research sites associated with the generally much higher than in those collected just before harvest (data not presented). Therefore, calculated nutrient removal rates for early-sampling sites were also greater (Table 4). Previous studies [15] also showed stover nutrient removal to be lower when based on material collected during machine harvest than on hand samples collected near physiologic maturity. This was especially true for the moderate removal rate since those samples included primarily cob and upper plant parts. For the high-removal treatments, nutrient removal estimates were

USDA-ARS Resilient Economic Agricultural Practices (REAP) and Sun Grant Regional Partnership

\begin{tabular}{|c|c|c|c|c|c|}
\hline Factor & 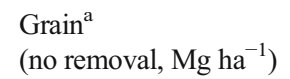 & 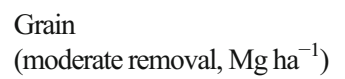 & $\begin{array}{l}\text { Grain } \\
\text { (high removal, } \mathrm{Mg} \mathrm{ha}^{-1} \text { ) }\end{array}$ & $\begin{array}{l}\text { Stover } \\
\text { (moderate removal, } \mathrm{Mg} \mathrm{ha}^{-1} \text { ) }\end{array}$ & 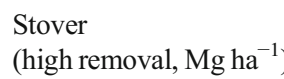 \\
\hline \multicolumn{6}{|l|}{ Rotation } \\
\hline Corn/corn & 9.84 & 10.19 & 10.24 & 4.01 & 6.97 \\
\hline $\begin{array}{l}\text { Corn/ } \\
\text { soybean }\end{array}$ & 9.08 & 9.24 & 9.00 & 3.45 & 7.89 \\
\hline $\operatorname{LSD}_{(0.10)}$ & NS & NS & NS & NS & NS \\
\hline \multicolumn{6}{|c|}{ Harvest method } \\
\hline Machine & 9.19 & 9.81 & 9.62 & 3.72 & 6.62 \\
\hline Calculated & 10.16 & 10.15 & 10.34 & 4.06 & 7.79 \\
\hline $\operatorname{LSD}_{(0.10)}$ & NS & NS & NS & NS & 0.98 \\
\hline
\end{tabular}

NS non-significant

${ }^{\text {a }}$ Grain yields at a water content of $155 \mathrm{~g} \mathrm{~kg}^{-1}$

${ }^{\mathrm{b}}$ Stover yield at a water content of $0 \mathrm{~g} \mathrm{~kg}^{-1}$ 
Table 7 Mean corn stover yield and nutrient removal for tillage and stover harvest methods associated with a meta-analysis of data representing 239 site-years of replicated field studies from 36 research sites associated with the USDA-ARS Resilient Economic Agricultural Practices (REAP) and Sun Grant Regional Partnership

\begin{tabular}{|c|c|c|c|c|}
\hline \multicolumn{5}{|l|}{ Factor: tillage } \\
\hline & Stover $^{\mathrm{a}}$ (moderate removal, $\mathrm{Mg} \mathrm{ha}^{-1}$ ) & $\mathrm{N}$ removal $\left(\mathrm{kg} \mathrm{ha}^{-1}\right)$ & P removal $\left(\mathrm{kg} \mathrm{ha}^{-1}\right)$ & $\mathrm{K}$ removal $\left(\mathrm{kg} \mathrm{ha}^{-1}\right)$ \\
\hline Conventional & 4.09 & 24.0 & 2.6 & 31.9 \\
\hline No tillage & 3.73 & 24.5 & 2.8 & 30.9 \\
\hline \multirow[t]{2}{*}{$\operatorname{LSD}_{(0.10)}$} & NS & NS & NS & NS \\
\hline & Stover $^{\mathrm{a}}$ (maximum removal, $\mathrm{Mg} \mathrm{ha}^{-1}$ ) & $\mathrm{N}$ removal $\left(\mathrm{kg} \mathrm{ha}^{-1}\right)$ & P removal $\left(\mathrm{kg} \mathrm{ha}^{-1}\right)$ & $\mathrm{K}$ removal $\left(\mathrm{kg} \mathrm{ha}^{-1}\right)$ \\
\hline Conventional & 7.05 & 43.3 & 4.6 & 59.0 \\
\hline No tillage & 7.26 & 49.7 & 6.0 & 63.8 \\
\hline $\operatorname{LSD}_{(0.10)}$ & NS & NS & NS & NS \\
\hline \multicolumn{5}{|c|}{ Factor: harvest method } \\
\hline & Stover $^{\mathrm{a}}$ (moderate removal, $\mathrm{Mg} \mathrm{ha}^{-1}$ ) & $\mathrm{N}$ removal $\left(\mathrm{kg} \mathrm{ha}^{-1}\right)$ & P removal $\left(\mathrm{kg} \mathrm{ha}^{-1}\right)$ & $\mathrm{K}$ removal $\left(\mathrm{kg} \mathrm{ha}^{-1}\right)$ \\
\hline Machine & 3.72 & 24.0 & 3.0 & 34.4 \\
\hline Calculated & 4.06 & 24.8 & 2.3 & 25.9 \\
\hline \multirow[t]{2}{*}{$\operatorname{LSD}_{(0.10)}$} & NS & NS & 0.5 & 5.4 \\
\hline & Stover $^{\mathrm{a}}$ (maximum removal, $\mathrm{Mg} \mathrm{ha}^{-1}$ ) & $\mathrm{N}$ removal $\left(\mathrm{kg} \mathrm{ha}^{-1}\right)$ & $\mathrm{P}$ removal $\left(\mathrm{kg} \mathrm{ha}^{-1}\right)$ & $\mathrm{K}$ removal $\left(\mathrm{kg} \mathrm{ha}^{-1}\right)$ \\
\hline Machine & 6.62 & 47.2 & 6.2 & 67.0 \\
\hline Calculated & 7.79 & 47.9 & 4.3 & 53.2 \\
\hline $\operatorname{LSD}_{(0.10)}$ & 1.01 & NS & NS & NS \\
\hline
\end{tabular}

NS non-significant

${ }^{\mathrm{a}}$ Stover yield at a water content of $0 \mathrm{~g} \mathrm{~kg}^{-1}$

generally higher, presumably because higher amounts of soluble elements such as $\mathrm{K}, \mathrm{Cl}$, and $\mathrm{NO}_{3}-\mathrm{N}$ were still present in the lower stalk fraction [22].

In an ancillary experiment conducted at University Park, PA, 2 years of stover data (2009-2010 and 2010-2011) showed significant nutrient removal differences when autumn versus spring harvest was compared. Averaged for the 2 years, mean stover yield and $\mathrm{N}, \mathrm{P}$, and $\mathrm{K}$ removal were $8,247,60,4.7$, and $60 \mathrm{~kg} \mathrm{ha}^{-1}$ when harvested in autumn compared to 5,983, $40,3.25$, and $18 \mathrm{~kg} \mathrm{ha}^{-1}\left(\operatorname{LSD}_{(0.05)}=740,11,0.78\right.$, and $12 \mathrm{~kg} \mathrm{ha}^{-1}$, respectively) when harvested the following spring. The rationale for this study was to determine a potential tradeoff between leaving stover in the field during the winter months for greater protection of soil resources and provision of wildlife habitat versus loss in stover yield and quality. However, for our purpose, it also helps illustrate the degree of change associated with measuring nutrient composition in corn stover harvested at different times after physiological maturity.

Finally, we envision that one of the most common longterm uses for the information presented in this article will be as reference data for simulation modeling [23] and validation of projections such as the revised Billion Ton Report [5]. To facilitate those types of activities, site-specific data from which these means were derived are currently being entered into the ARS REAPnet database [24]. The plan for the data contributed to that database is that following peer review and publication, it will be made publically available for further use and interpretation.

\section{Summary and Conclusions}

Mean corn grain and stover yields as well as N, P, and $\mathrm{K}$ removal representing 239 site-years of replicated field research associated with the SGRP are presented. Harvesting an average of 3.9 or $7.2 \mathrm{Mg} \mathrm{ha}^{-1}$ (1.7 or 3.2 tons $\mathrm{ac}^{-1}$ ) of corn stover resulted in a slight increase in grain yield at 57 and $51 \%$ of the research sites. Average no-till grain yields were significantly lower than with conventional tillage when stover was not removed, but equivalent when it was harvested. Presumably stover harvest helped mitigate many traditional residue management problems such as $\mathrm{N}$ immobilization and reduced soil temperatures. Overall, grain yields for all three stover harvest treatments were highest within the center portion of the Corn Belt $\left(-88^{\circ}\right.$ to $-94^{\circ} \mathrm{W}$ longitude and $41^{\circ}$ to $42^{\circ} \mathrm{N}$ latitude). Moderate stover harvest increased $\mathrm{N}, \mathrm{P}$, and $\mathrm{K}$ removal by $24,2.7$, and $31 \mathrm{~kg} \mathrm{ha}^{-1}$, respectively, while high removal increased them by $47,5.5$, and $62 \mathrm{~kg} \mathrm{ha}^{-1}$, respectively. We suggest this information be used primarily to verify simulation modeling and projections of available feedstock such as those in the revised Billion Ton Report [5] rather than for making site-specific management decisions regarding stover harvest.

Acknowledgement The U.S. Department of Agriculture offers its programs to all eligible persons regardless of race, color, age, sex, or national 
origin and is an equal-opportunity employer. This research was funded by the USDA-Agricultural Research Service as part of the USDA-ARS Resilient Economic Agricultural Practices (REAP) project with additional funds from the North Central Regional Sun Grant Center at South
Dakota State University through a grant provided by the U.S. Department of Energy (DOE) - Office of Biomass Programs [now known as the Bioenergy Technology Office (BETO)] under award number DE-FC3605GO85041.

\section{Appendix}

Table 8 Soil classification (see Table 1 for soil management and other information associated with each experimental site) information for Sun Grant Corn Stover Regional Partnership sites

\begin{tabular}{lll}
\hline Site & Soil series & Classification \\
\hline $1-9$ & Clarion & Fine-loamy, mixed, superactive, mesic Typic Hapludolls \\
$1-9$ & Nicollet & Fine-loamy, mixed, superactive, mesic Aquic Hapludolls \\
$1-9$ & Webster & Fine-loamy, mixed, superactive, mesic Typic Endoaquolls \\
$10-11$ & Muscatine & Fine-silty, mixed, superactive, mesic Aquic Hapludolls \\
$12-13$ & Flanagan & Fine, smectitic, mesic Aquic Argiudolls \\
$14-15$ & Clarksdale & Fine, smectitic, mesic Udollic Endoaqualfs \\
$16-17$ & Drummer & Fine-silty, mixed, superactive, mesic Typic Endoaquolls \\
$18-20$ & Barnes & Fine-loamy, mixed, superactive, frigid Calcic Hapludolls \\
$18-20$ & Aastad & Fine-loamy, mixed, superactive, frigid Pachic Hapludolls \\
$21-22$ & Garwin & Fine-silty, mixed, superactive, mesic Typic Endoaquolls \\
$23-24$ & Waukegan & Fine-silty over sandy or sandy-skeletal, mixed, superactive, mesic Typic Hapludolls \\
$25-26$ & Normania & Fine-loamy, mixed, superactive, mesic Aquic Hapludolls \\
$25-26$ & Ves & Fine-loamy, mixed, superactive, mesic Calcic Hapludolls \\
$25-26$ & Webster & Fine-loamy, mixed, superactive, mesic Typic Endoaquolls \\
27 & Yutan & Fine-silty, mixed, superactive, mesic Mollic Hapludalfs \\
$27-29$ & Tomek & Fine, smectitic, mesic Pachic Argiudoll \\
$28-29$ & Filbert & Fine, smectitic, mesic Vertic Argialbolls \\
$30-33$ & Opequon & Clayey, mixed, active, mesic Lithic Hapludalfs \\
$30-33$ & Hagerstown & Fine, mixed, semiactive, mesic Typic Hapludalfs \\
$34-35$ & Kranzburg & Fine-silty, mixed, superactive, frigid Calcic Hapludolls \\
$34-35$ & Brookings & Fine-silty, mixed, superactive, frigid Pachic Hapludolls \\
36 & Goldsboro & Fine-loamy, siliceous, subactive, thermic Aquic Paleudults \\
36 & Lynchburg & fine-loamy, siliceous, semiactive, thermic Aeric Paleaquults \\
36 & Coxville & Fine, kaolinitic, thermic Typic Paleaquults \\
\hline & &
\end{tabular}

\section{References}

1. Keeler BL, Krohn BJ, Nickerson TA, Hill JD (2013) U.S. federal agency models offer different visions for achieving renewable fuel standard (RFS2) biofuel volumes. Environ Sci Technol 47:1009510101

2. Perlack RD, Wright LL, Turhollow AF, Graham RL, Stokes BJ, Erbach DC (2005) Biomass as feedstock for a bioenergy and bioproducts industry: the technical feasibility of a billion-ton annual supply. DOE/GO-102005-2135 and ORNL/TM-2005/66. http:// feedstockreview.ornl.gov/pdf/billion_ton_vision.pdf. Accessed 7 Jan 2014

3. USDA-National Agricultural Statistics Service (NASS) (2013) Data and Statistics [online]. Washington DC, USA. http://www.nass.usda.gov/ Data_and_Statistics/Quick_Stats/index.asp. Accessed 7 Jan 2014

4. Schroeder J (2011) Finding fuel in agricultural waste. Domestic Fuel. http://domesticfuel.com/2011/01/27/finding-fuel-in-agriculturalwaste/. Accessed 7 Jan 2014

5. U.S. Department of Energy (2011) U.S. billion-ton update: biomass supply for a bioenergy and bioproducts industry. Perlack RD, Stokes
BJ (leads), ORNL/TM-2011/224. Oak Ridge National Laboratory, Oak Ridge, TN. 227 pp

6. Lavigne A, Powers SE (2007) Evaluating fuel ethanol feedstocks from energy policy perspectives: a comparative energy assessment of corn and corn stover. Energy Pol 35:5918-5930

7. Searchinger T, Heimlich R, Houghton RA, Dong F, Elobeid A, Fabiosa J, Tokgoz S, Hayes D, Yu T (2008) Use of U.S. croplands for biofuels increases greenhouse gases through emissions from land use change. Science 319:1238-1240

8. Moore KJ, Karlen DL, Lamkey KR (2013) Future prospects for corn as a biofuel crop. In: Goldman SL, Kole C (eds) Compendium of bioenergy plants: corn. CRC Press, Boca Raton, pp 331-352

9. Biomass Research and Development Board (BRDB) (2008) Increasing feedstock production for biofuels: economic drivers, environmental implications and the role of research. http://www. ascension-publishing.com/BIZ/HD4-Brdi.pdf. Accessed 7 Jan 2014

10. Nelson RG (2002) Resource assessment and removal analysis for corn stover and wheat straw in the Eastern and Midwestern United States - rainfall and wind-induced soil erosion methodology. Biomass Bioenergy 22:349-363 
11. Duffy MD (2014) Estimated costs of crop production in Iowa-2014. FM-1712 (revised January 2014) Iowa State University Extension and Outreach, Ames, IA. https://store.extension.iastate.edu/ ItemDetail.aspx?ProductID=1793. Accessed 7 Jan 2014

12. Johnson JMF, Papiernik SK, Mikha MM, Spokas KA, Tomer MD, Weyers SL (2010) Soil processes and residue harvest management. In: Lal R, Stewart BA (eds) Carbon management, fuels, and soil quality. Taylor \& Francis, New York, pp 1-44

13. Wilhelm WW, Hess JR, Karlen DL, Johnson JMF, Muth DJ, Baker JM, Gollany HT, Novak JM, Stott DE, Varvel GE (2010) Review: balancing limiting factors and economic drivers for sustainable Midwestern US agricultural residue feedstock supplies. Ind Biotechnol 6:271-287

14. Wilhelm WW, Johnson JMF, Karlen DL, Lightle DT (2007) Corn stover to sustain soil organic carbon further constrains biomass supply. Agron J 99:1665-1667

15. Karlen DL, Birrell SJ, Hess JR (2011) A five-year assessment of corn stover harvest in Central Iowa, USA. Soil Tillage Res 115-116:47-55

16. Karlen DL, Varvel GE, Johnson JMF, Baker JM, Osborne SL, Novak JM, Adler PR, Roth GW, Birrell SJ (2011) Monitoring soil quality to assess the sustainability of harvesting corn stover. Agron J 103:288295

17. Karlen DL, Birrell SJ, Wirt AR (2012). Corn stover harvest strategy effects on grain yield and soil quality indicators. In: Ernst O, Pérez M, Terra J, Barbazán M (eds) Striving for sustainable high productivity through improved soil and crop management. Proc. of the 19th
Triennial ISTRO conference, Montevideo, Uruguay. Special Issue: Agrociencia Uruguay. ISSN 1510-0839

18. Blanco-Canqui H, Lal R (2009) Crop residue removal impacts on soil productivity and environmental quality. Crit Rev Plant Sci 28:139163

19. Karlen DL, Hunt PG, Campbell RB (1984) Crop residue removal effects on corn yield and fertility of a Norfolk sandy loam. Soil Sci Soc Am J 48:868-872

20. Karlen DL (2004) Cropping systems: rain-fed maize-soybean rotations of North America. In: Goodman RM (ed) Encyclopedia of plant and crop science. Marcel Dekker, New York, pp 358-362

21. Muth DJ Jr, McCorkle DS, Koch JB, Bryden KM (2012) Modeling sustainable agricultural residue removal on the subfield scale. Agron J 104:970-981

22. Hoskinson RL, Karlen DL, Birrell SJ, Radtke CW, Wilhelm WW (2007) Engineering, nutrient removal and feedstock conversion evaluations of four corn stover harvest scenarios. Biomass Bioenergy 31: $126-136$

23. Karlen DL (2010) Corn stover feedstock trials to support predictive modeling. Glob Chang Biol - Bioenergy 2:235-247

24. Del Grosso SJ, White JW, Wilson G, Vandenberg B, Karlen DL, Follett RF, Johnson JMF, Franzluebbers AJ, Archer DW, Gollany HT, Liebig MA, Ascough J, Reyes-Fox M, Pellack L, Starr J, Barbour N, Polumsky RW, Gutwein M, James D (2013) Introducing the GRACEnet/REAP data contribution, discovery, and retrieval system. J Environ Qual 42:1274-1280 